\title{
Evaluation of Cladophora laetevirens (Chlorophyta) and Patella caerulea (Mollusca) as bioindicators for heavy metals Pollution at Al-Hanyaa Mediterranean Coast, Libya.
}

\author{
Magda F. El-Adl ${ }^{1}$ and Ahmed S Bream ${ }^{2}$ \\ 1- Botany Department, Faculty of Science, Damietta University-Egypt. Current address: \\ Botany Department, Faculty of Education (Al-Qubba), Omar Al-Mukhtar University, \\ Al- Beidaa, Libya; E.mail: magdaeladl@yahoo.com. \\ 2- Zoology Department, Faculty of Sciences, Al - Azhar University, Nasr City, Cairo, Egypt. \\ E.mail: ahmed_bream@yahoo.com
}

\section{ABSTRACT}

This study was designed to evaluate the new record seaweed Cladophora laetevirens (Dillwyn) Kützing (Chlorophyta: Cladophorales) and Patella caerulea Linnaeus (Mollusca: Gastropoda) as bioaccumulating agents. The samples of two species were collected from polluted and unpolluted (reference) sites from the rocky shores of Al-Hanyaa coasts, Libya. Zinc $(\mathrm{Zn})$, cadmium $(\mathrm{Cd})$, lead $(\mathrm{Pb})$ and copper $(\mathrm{Cu})$ were determined using voltammetric technique. The results exhibited that, $\mathrm{Cu}$ occupied the highest level $\left(559.15 \pm 68.55 \mu \mathrm{g} \mathrm{g}^{-1}\right.$ fresh weights) among metals accumulated by $\mathrm{Cl}$. laetevirens in polluted site, followed by $\mathrm{Pb}$ and vice versa in unpolluted site, where $\mathrm{Pb}$ attained $179.71 \pm 31.19 \mu \mathrm{g} \mathrm{g}^{-1}$ fresh weight. Despite that $\mathrm{Cd}$ has minimal concentration levels (either in $\mathrm{Cl}$. laetevirens or $\mathrm{P}$. caerulea tissues, at both sites), it recorded maximal bioaccumulation factors (BAFs) for $\mathrm{Cl}$. laetevirens in both sites. Metal pollution index (MPI) recorded in a descending order as: $\mathrm{Cl}$. laetevirens $>P$. caerulea gut $>P$. caerulea muscle for both sites. Cadmium was positively correlated with $\mathrm{Cu}$ and $\mathrm{Pb}$ in both sites. The present data and their analysis proved the consistency, appropriateness, tolerance and reliability of $\mathrm{Cl}$. laetevirens as a bioindicator regardless the metal concentration levels in seawater. These results confirmed that $\mathrm{Cl}$. laetevirens is the strongest accumulator for $\mathrm{Cu}, \mathrm{Pb}$ and $\mathrm{Cd}$ while $P$. caerulea is a potential accumulator for $\mathrm{Zn}$.

Keywords: Cladophora laetevirens; Patella caerulea; heavy metals; Al-Hanyaa; Libya; bioindicators

\section{INTRODUCTION}

Heavy metal pollution is one of the most important challenges on the earth's surface at the present time, where the discharge of dangerous inorganic compounds of natural and anthropogenic sources, widely pollute the aquatic system (Marcovecchio, 2004). The same author reported that the contamination, with non-degradable heavy metals, is more threatened the estuaries and semiclosed coastal ecosystems, especially near highly populated or industrial areas.

Although some heavy metals are essential in trace concentrations for the protection of body metabolism, growth and general well being of living organisms, they can lead to poisoning of organisms at higher concentrations (Bradh, 2005). Heavy metals in sediment samples can be changed by organic matter content, grain size, soil composition, $\mathrm{pH}$ and oxidation-reduction potential. Furthermore, seawater may contain very low concentration levels of heavy metals (Förstner, 1985). Thus, it was not difficult to think about the use of organisms that adsorb and accumulate heavy metals to assess the contamination levels in any aquatic ecosystem. Organisms were found to be a potential biotechnological alternative method than 
physicochemical methods (Zabochnicka-Swiatek and Krzywonos, 2014). So, the determination of heavy metal concentrations using algae is preferred than seawater and sediment samples, because of algal properties such as their distribution, size, longevity, presence at polluted sites, ability to accumulate metals and ease of identification (Conti and Cecchetti, 2003).

The coastal aquatic ecosystem of Al-Hanyaa region, Libya, has recently received much attention due to sewage influent into some of its sites. So, this investigation was carried out to evaluate the potential suitability of the new record marine benthic algae, Cladophora laetevirens (Chlorophyta), and its allied limpet $P$. caerulea (Gastropoda), inhabiting Al-Hanyaa coast, as bioindicators of heavy metals pollution.

\section{MATERIALS AND METHODS}

\section{The study area}

Al-Hanyaa is a coastal small city, situated on the northeastern Mediterranean coast of Libya. It lies at $32^{\circ} .45^{\prime} \mathrm{N}$ and $21^{\circ} .30^{\prime} \mathrm{E}$, and has a rocky shore extends about $4 \mathrm{~km}$ along shoreline and suffers from sewage pollution in some sites. The bottom of the intertidal zones is characterized by several boulders of variable sizes in addition to fast area of flat rocks which provide good substrates for growing of algal mats and shelters for gastropod $P$. caerulea and other marine benthic organisms.

Two sites were chosen during this study. The first site, polluted, lies adjacent to a sewage outlet at $32^{\circ} 50^{\prime} 44^{\prime \prime} \mathrm{N}$ and $21^{\circ} 31^{\prime} 12 \mathrm{E}$. The second one is a reference (unpolluted) site, lies at $32^{\circ} 50^{\prime} 5^{\prime \prime} \mathrm{N}$ and $21^{\circ} 30^{\prime} 22 \mathrm{E}$ and is far about $3 \mathrm{Km}$ westerly from the first site (Fig.1).

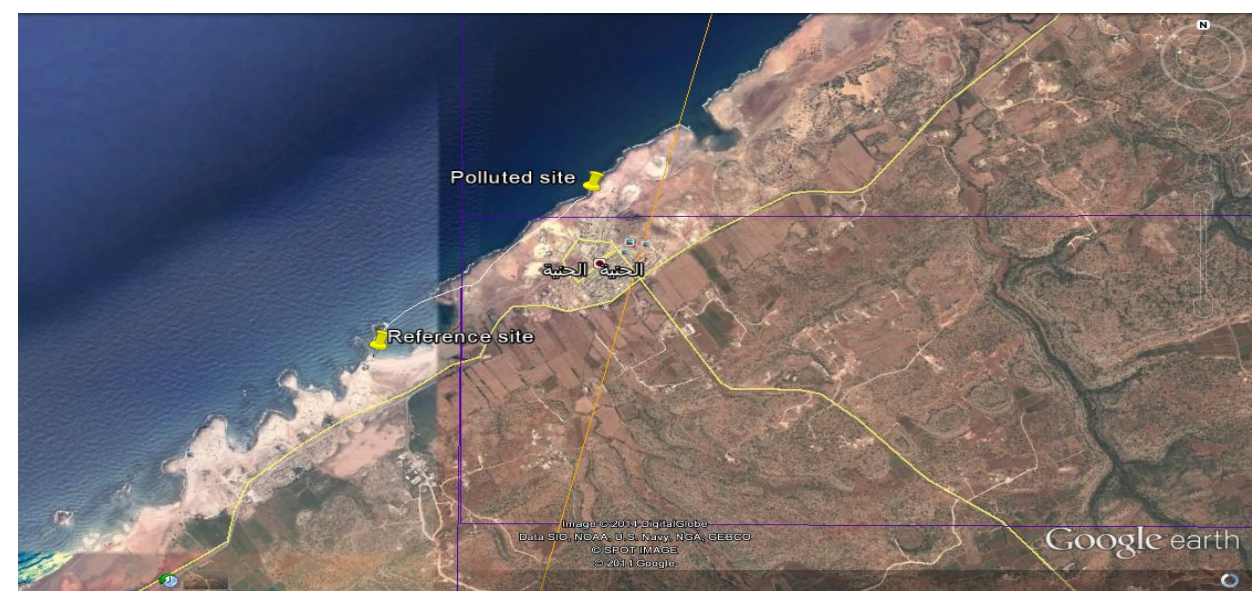

Fig. 1: Map of Al- Hanyaa, Libya on the Mediterranean Sea.

\section{Taxonomy of the studied organisms}

Cladophora laetevirens was identified using taxonomical keys; the World Register of Marine Species (WoRMS Editorial Board, 2013) and Abbott (1999). It is worth mentioning that $\mathrm{Cl}$. laetevirens was documented as a new record on the Libyan coastline by El-Adl (2014). Whereas P. caerulea was identified using different taxonomical keys (Borradaile et al., 1977).

\section{Sample collection}

Water samples from the reference and polluted sites were collected using sterile 1 liter plastic container. Samples of $C l$. laetevirens and $P$. caerulea with the same ages, size and healthy in appearance were handpicked during low tide at winter 2014. 
The collected samples were rinsed thoroughly with seawater on-site after collection, placed in plastic bags with information on dates and place, and transferred immediately to the laboratory as soon as possible. At the laboratory, samples were initially washed under a jet of tap water and rinsed in distilled water to remove any mineral particles or organisms.

\section{Analytical methods}

At the laboratory, $P$. caerulea was dissected where gut and muscles were separated. For analyses, one gram of each sample was digested in $20 \mathrm{ml}$ nitric acid and $3 \mathrm{ml}$ perchloric acid in Kjeldahl apparatus until white fumes appear and organism's tissues dissolved completely. The samples were allowed to cool after that, $10 \mathrm{ml}$ of $\mathrm{HCl}(1: 1)$ were added and complete digestion process continued till the solutions turn clear. Finally, distilled $\mathrm{H}_{2} \mathrm{O}$ was added to digested samples till $50 \mathrm{ml}$ according to AOAC (1980). The concentration of four metals ( $\mathrm{Zn}, \mathrm{Cd}, \mathrm{Pb}$ and $\mathrm{Cu}$ ) in seawater samples, Cladophora and P. caerulea (gut and muscle) have been measured using hanging mercury dropping electrode (HMDE), reference electrode $(\mathrm{Ag} / \mathrm{AgCl}$ $3 \mathrm{MKCl}$ ) and platinum auxiliary electrode, model VA 746 trace analyzer coupled to a model VA 747 stand, Metrohm co.

\section{Indices of pollution:}

\section{The metal pollution index (MPI):}

MPI was used to compare the total content of heavy metals at locations studied according to Usero et al. (1996) and represented by the following formula:

$$
\mathrm{MPI}=\left(\mathrm{Cf}_{1} \times \mathrm{Cf}_{2} \times \mathrm{Cf}_{3} \ldots \ldots \mathrm{Cf}_{\mathrm{n}}\right)^{1 / \mathrm{n}}
$$

Where $\mathrm{Cf}_{\mathrm{n}}=$ Concentration for metal in the sample.

\section{Bioaccumulation factors (BAFs):}

BAFs of the studied contaminants were calculated based on Harrahy and Clements (1997) formula: $\mathrm{BAF}=\mathrm{CS} / \mathrm{Cw}$

Where $\mathrm{CS}=$ Concentration of the metal in the sample.

$\mathrm{Cw}=$ Concentration of the metal in water.

\section{Statistical analysis:}

The data were analyzed using SPSS statistical program. Pearson's correlation was used to measure the strength of the association between heavy metal concentrations in $\mathrm{Cl}$. laetevirens and $\mathrm{P}$. caerulea. ANOVA test was employed to differentiate between means.

\section{RESULTS}

\section{Heavy metal concentrations in seawater samples}

As shown in Table (1), the discharge of sewage pollutants lead to an increase in heavy metal concentration levels in seawater compared with those recorded from the reference site.

Table 1: Mean values of heavy metal concentrations detected in seawater samples collected from AlHanyaa city, Libya compared with the corresponding seawater standard values of EPA $(\bar{X} \pm \mathrm{SD}$ $\left.\mu \mathrm{g} 1^{-1}, \mathrm{n}=3\right)$.

\begin{tabular}{|c|c|c|c|}
\hline Metals/Sites & Site I (Reference) & Site II (Polluted) & EPA (2014)* \\
\hline $\mathrm{Zn}$ & $5.40 \pm 1.20$ & $7.40 \pm 0.140$ & 81 \\
\hline $\mathrm{Pb}$ & $0.20 \pm 0.05$ & $0.40 \pm 0.170$ & 1.8 \\
\hline $\mathrm{Cd}$ & $0.03 \pm 0.004$ & $0.07 \pm 0.005$ & 1 \\
\hline $\mathrm{Cu}$ & $0.24 \pm 0.06$ & $0.60 \pm 0.160$ & 3.1 \\
\hline
\end{tabular}

* EPA (2014) shows maximum contamination level in seawater sample. 
The present results revealed that, the level of heavy metal concentrations in both reference and polluted sites showed the same trend, and was arranged in the following the order: $\mathrm{Zn}>\mathrm{Cu}>\mathrm{Pb}>\mathrm{Cd}\left(\mu \mathrm{g} \mathrm{g}^{-1}\right.$ fresh weight). It is noticeable that $\mathrm{Zn}$ concentration levels were the highest among metals determined in both seawater types. However, the recorded concentration levels at both sites were very low than the standard values (Table 1).

ANOVA results verified that the variations of metal levels in seawater are very highly significant, regardless the type of sites $(\mathrm{F}=45.7467, \mathrm{df}=3, \mathrm{P}<0.01$, Table 2$)$. Nonetheless, there is no significantly difference between the studied sites. The variance percentage of $\mathrm{Zn}(95.89 \%)$ and $\mathrm{Cu}(3.12 \%)$ may be responsible for this increment of significance.

Table 2: Two - way ANOVA for seawater heavy metals at Al-Hanyaa, Libya.

\begin{tabular}{|l|c|c|c|c|c|c|}
\hline Source of Variance & SS & df & MS & F & P-value & F crit \\
\hline Metals & 56.75335 & 3 & 18.91778 & 45.7467 & 0.005277 & 9.276628 \\
\hline Sites & 0.845 & 1 & 0.845 & 2.043366 & 0.248214 & 10.12796 \\
\hline Error & 1.2406 & 3 & 0.413533 & & & \\
\hline
\end{tabular}

\section{Heavy metal concentrations in $\mathbf{C l}$. laetevirens and $\boldsymbol{P}$. caerulea}

Heavy metal concentration levels accumulated in $\mathrm{Cl}$. laetevirens collected from polluted and reference sites were higher than those detected in P. caerulea tissues, except $\mathrm{Zn}$ determined in P. caerulea gut (Table 3 ).

The results also showed that, the metal concentrations in $\mathrm{Cl}$. laetevirens was arranged in the following descending order: $\mathrm{Pb}(197.7 \pm 31.19)>\mathrm{Cu}(165 \pm 18.19)>$ $\mathrm{Zn}(44.00 \pm 14.35)>\mathrm{Cd}\left(38.62 \pm 2.44 \mu \mathrm{g} \mathrm{g}^{-1}\right.$ fresh weight $)$ in reference site compared to $\mathrm{Cu}(559.15 \pm 68.55)>\mathrm{Pb}(207.51 \pm 23.82)>\mathrm{Zn}(135.39 \pm 14.00)>\mathrm{Cd}(77.19 \pm$ $1.22 \mu \mathrm{g} \mathrm{g}^{-1}$ fresh weight) in polluted site. For $P$. caerulea gut heavy metals, $\mathrm{Zn}$ concentration was the highest level at both sites followed by $\mathrm{Pb}, \mathrm{Cu}$ and $\mathrm{Cd}$. These metals were represented in the following descending order: $\mathrm{Zn}(133.44 \pm 18.13)>\mathrm{Pb}$ $(47.04 \pm 4.24)>\mathrm{Cu}(35.30 \pm 4.22)>\mathrm{Cd}\left(2.30 \pm 0.32 \mu \mathrm{g} \mathrm{g}^{-1}\right.$ fresh weight $)$ in reference site, increased remarkable with the same pattern to $\mathrm{Zn}(241.93 \pm 41.37)>\mathrm{Pb}(60.37 \pm$ $3.29)>\mathrm{Cu}(45.06 \pm 7.80)>\mathrm{Cd}\left(4.28 \pm 0.63 \mu \mathrm{g} \mathrm{g}^{-1}\right.$ fresh weight $)$ in polluted site.

In $P$. caerulea muscles, the concentrations of measured heavy metals were remarkably lower than those detected in gut (Table 3). The results exhibited high levels of $\mathrm{Pb}$, followed by $\mathrm{Zn}$, and $\mathrm{Cu}$, and declined sharply for $\mathrm{Cd}$, but with slight increase in polluted site. It is obvious that, $P$. caerulea gut has more ability to accumulate metals from the two sites more than muscle. In addition, $P$. caerulea gut accumulated a considerable concentration of $\mathrm{Zn}$ more than $\mathrm{Cl}$. laetevirens.

Table 3: Mean concentration levels of heavy metals $\left(\bar{X}_{ \pm} \mathrm{SD} \mu \mathrm{g} \mathrm{g}^{-1}\right.$ fresh weight) detected in $C l$.

laetevirens and P. caerulea living on the rocky shores of Al-Hanyaa city, Libya.

\begin{tabular}{|c|c|c|c|c|c|c|}
\hline Sites & \multicolumn{3}{|c|}{ Reference site } & \multicolumn{3}{c|}{ Polluted site } \\
\hline Species & Cl. laetevirens & \multicolumn{2}{|c|}{ P. caerulea } & Cl. laetevirens & Muerulea \\
\hline Metals & & Gut & Muscle & & Gut & Muscle \\
\hline $\mathrm{Zn} \mu \mathrm{g} / \mathrm{g}$ & $44.00 \pm 14.35$ & $133.44 \pm 18.13$ & $18.26 \pm 0.02$ & $135.39 \pm 14.00$ & $241.93 \pm 41.37$ & $27.36 \pm 3.60$ \\
\hline $\mathrm{Pb} \mu \mathrm{g} / \mathrm{g}$ & $179.7 \pm 31.188$ & $47.35 \pm 4.51$ & $24.98 \pm 0.54$ & $207.51 \pm 23.82$ & $60.37 \pm 3.29$ & $32.41 \pm 2.69$ \\
\hline $\mathrm{Cd} \mu \mathrm{g} / \mathrm{g}$ & $38.62 \pm 2.44$ & $2.30 \pm 0.32$ & $1.46 \pm 0.41$ & $77.19 \pm 1.22$ & $4.28 \pm 0.63$ & $3.60 \pm 0.56$ \\
\hline $\mathrm{Cu} \mu \mathrm{g} / \mathrm{g}$ & $165 \pm 18.187$ & $35.30 \pm 4.22$ & $7.2 \pm 2.10$ & $559.15 \pm 68.55$ & $45.06 \pm 7.80$ & $16.76 \pm 1.75$ \\
\hline
\end{tabular}

One-way ANOVA verified that all metals, regardless the type of sites, were exceedingly significant at $p<0.001$ (Table 4). Also, the difference between $\mathrm{Cl}$. laetevirens and $P$. caerulea was highly significant in both sites, except for $P$. caerulea gut in reference site $(p>0.05)$. The calculated variance percentage showed that $\mathrm{Cu}$ 
(73.34\%), Zn (14.45\%) and $\mathrm{Pb}(10.45 \%)$ were responsible for the elevation in this significance. Also, the variance percentage of $\mathrm{Cl}$. laetevirens $(21.56 \%)$ and $P$. caerulea gut $(5.2 \%)$ in polluted site may be responsible for an increase in species significance.

Table 4: One-way ANOVA for metals and tested organisms at Al-Hanyaa, Libya.

\begin{tabular}{|c|c|c|c|c|c|c|c|c|c|c|c|c|}
\hline Species & & ss & df & MS & F-value & P-level & Metals & ss & df & MS & F-value & P- level \\
\hline \multicolumn{13}{|l|}{ Reference site } \\
\hline CL. laetevirens & & 52131 & 3 & 17377.2 & 45.873 & .000 & $\mathbf{Z n}$ & 132527.8 & 5 & 26505.57 & 53.39 & .000 \\
\hline P. caerulea & gut & 529.03 & 3 & 509.68 & 1.629 & .258 & Cd & 14926.33 & 5 & 2985.27 & 2410.14 & .000 \\
\hline P. caerulea & muscle & 29886. & 3 & 9962.29 & 84.083 & .000 & $\mathbf{P b}$ & 96872.44 & 5 & 19374.49 & 79.95 & .000 \\
\hline Polluted site & & & & & & & $\mathbf{C u}$ & 691374.3 & 5 & 138274.8 & 153.71 & .000 \\
\hline Cl. laetevirens & & 420797 & 3 & 140265 & 102.698 & .000 & & & & & & \\
\hline P. caerulea & gut & 109379 & 3 & 36459.7 & 69.162 & .000 & & & & & & \\
\hline P. caerulea & muscle & 1459.5 & 3 & 486.52 & 82.525 & .000 & & & & & & \\
\hline
\end{tabular}

Data illustrated in Fig. 2 (A and B), elucidated the ability of $\mathrm{Cl}$. laetevirens to accumulate heavy metals efficiently than $P$. caerulea. BAFs for $\mathrm{Cd}$ was followed by $\mathrm{Pb}, \mathrm{Cu}$ and $\mathrm{Zn}$ in $\mathrm{Cl}$. laetevirens inhabiting the reference site, whereas, it followed by $\mathrm{Cu}, \mathrm{Pb}$ and $\mathrm{Zn}$ in $\mathrm{Cl}$. laetevirens affected by sewage discharge. $\mathrm{Pb}$ dominates the metals accumulated by $P$. caerulea (gut and muscle) in both sites.

For comparing the common effects of the total heavy metals on the two studied sites, MPI was calculated and represented in figure 3 (A\&B). The results revealed that MPI values were higher in $\mathrm{Cl}$. laetevirens than $P$. caerulea gut and muscle at both sites. Where, their values attained 84.25 and $186.6 \mu \mathrm{g} \mathrm{g}^{-1}$ for $\mathrm{Cl}$. laetevirens comparing with 26.72 and 40.96 for $P$. caerulea gut and 8.32 and 15.21 for its muscle in reference and polluted sites, respectively (Fig. 3 A). The previous figure proves the comparable affinity of the two organisms in accumulating heavy metals at both sites, where this accumulation seems to proportion to the concentration of such metals in seawater.

Data plotted in Fig. 3B for MPI showed the positive correlation relationship between the two sites. This relationship emphasized the efficiency of the tested organisms for bioaccumulation of metals regardless their concentrations in the seawater $\left(\mathrm{R}^{2}=0.991\right)$. Reviewing Table $(5)$, it was found that $\mathrm{Cd}$ positively correlated with $\mathrm{Cu}$ and $\mathrm{Pb}$ in polluted and reference sites at $\mathrm{P}<0.01$. Also, $\mathrm{Cu}$ significantly correlated with $\mathrm{Pb}$ in both sites.
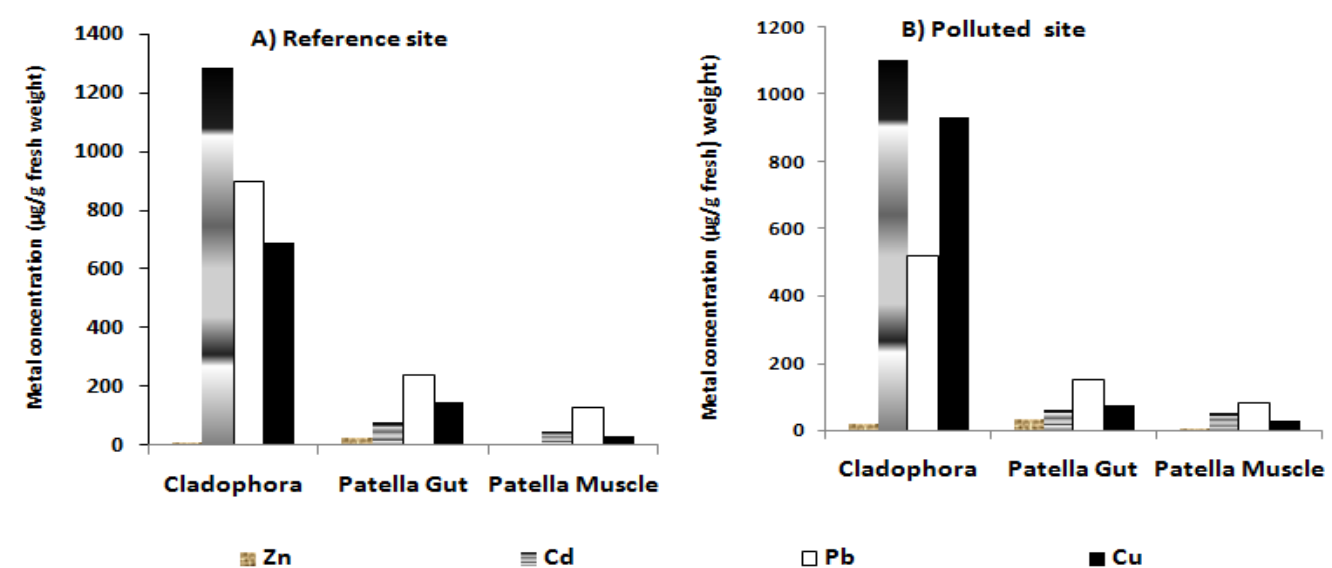

Fig. 2: Bioaccumulation factors of heavy metals for Cl. laetevirens and P. caerulea collected from AlHanyaa rocky shore, Libya. 

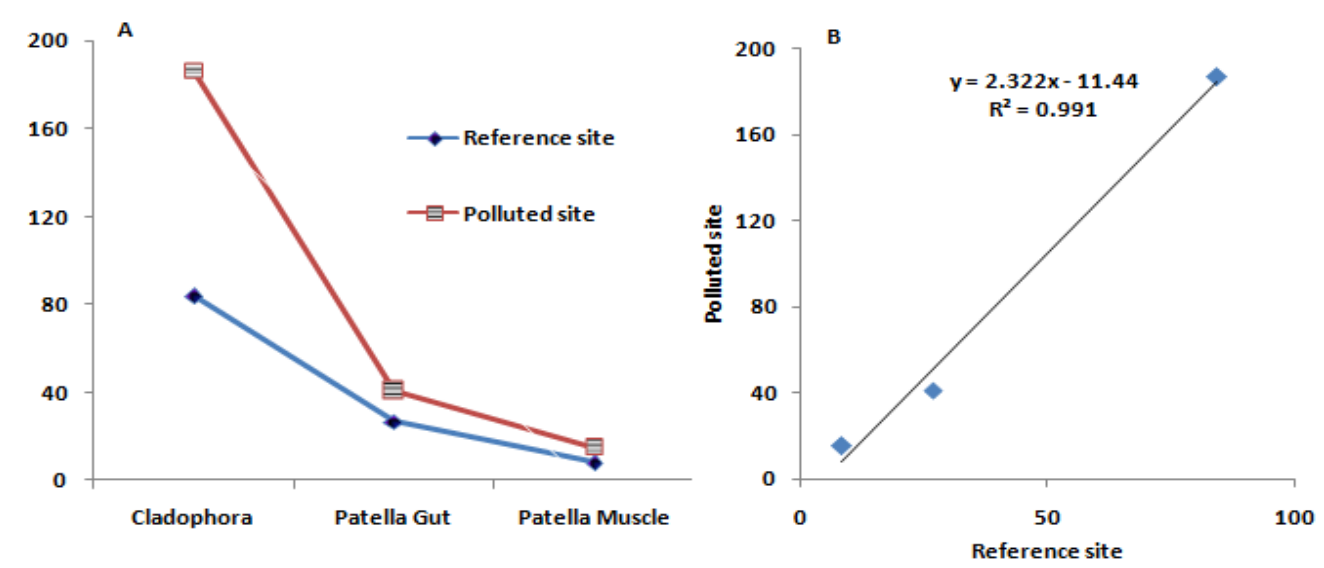

Fig. 3 A: MPI values for $C l$. laetevirens and P. caerulea in polluted and reference sites. B: Correlation between MPI of both organisms in polluted $v s$. reference site at Al- Al-Hanyaa, Libya. $\mathrm{n}=3$.

Table 5: Pearson correlation for heavy metals in polluted and reference sites at Al-Hanyaa, Libya.

\begin{tabular}{|c|c|c|c|c|c|c|c|c|c|}
\hline \multicolumn{5}{|c|}{ Polluted site } & \multicolumn{5}{|c|}{ Reference site } \\
\hline & Cd & $\mathbf{C u}$ & $\mathbf{P b}$ & $\mathbf{Z n}$ & & Cd & $\mathbf{C u}$ & $\mathbf{P b}$ & $\mathrm{Zn}$ \\
\hline Cd & 1 & $0.991 * *$ & $0.976 * *$ & -0.064 & Cd & 1 & $0.9652 * *$ & $0.9786 * *$ & -0.3228 \\
\hline $\mathbf{C u}$ & & 1 & $0.974 * *$ & -0.22 & $\mathbf{C u}$ & & 1 & $0.979 * *$ & -0.274 \\
\hline $\mathbf{P b}$ & & & 1 & -0.072 & $\mathbf{P b}$ & & & 1 & -0.223 \\
\hline $\mathbf{Z n}$ & & & & 1 & Zn & & & & 1 \\
\hline
\end{tabular}

\section{DISCUSSION}

Coastal waters receiving sewage and other effluents can have considerably higher heavy metals concentrations than that of the open sea. This fact can be applied on the studied area which suffered from different types of wastes either from the open sea like ship wastes or from the anthropogenic activities on land as well as the nature of rocks and its erosion rate.

The levels of metals investigated in polluted and reference water samples were lower than that of the maximum concentration levels recommended by EPA (2014). The data attained clarify that $\mathrm{Zn}$ concentration levels were higher than the levels of $\mathrm{Cu}, \mathrm{Cd}$ and $\mathrm{Pb}$ in both water types. In accordance with Pérez-López et al. (2003), the results showed an increase in heavy metal levels in seawater by increasing the anthropogenic activities. Anyhow, heavy metal contaminated seawater may influence the marine organism's health. According to the findings of Chapman et al. (1996), algal species that failed to eliminate heavy metals through excretion, compartmentalization or metabolically immobilization subjected to adverse and toxic effects.

Epizoic and/or benthic $\mathrm{Cl}$. laetevirens was found to storage higher levels of metals than $P$. caerulea tissues, except in the case of $\mathrm{Zn}$ because of the algal high negative surface charge and its affinity for heavy metal cations emitted through the anthropogenic metal emissions (Rao, 1986). The increments in metal levels in $\mathrm{Cl}$. laetevirens increases the metal levels in $P$. caerulea gut through the food chain, this agree with Pérez - Lòpez et al. (2003).

It is obvious that, $\mathrm{Zn}$ was bioconcentrated in $P$. caerulea gut in considerable levels in both reference and polluted sites. This result was similar with that attained by Nott and Nicolaidou $(1989,1994)$ who referred to Mollusca as efficient bioindicators and that of Wang and Caihuan (2002) who reported that, marine gastropods are 
known to accumulate high metal concentrations in their tissues, especially in the digestive glands.

Lozano et al. (2003) reported that, algal samples containing lower than $2 \mu \mathrm{g} \mathrm{g}^{-1}$ $\mathrm{Cd}$ of dry weight can be considered not polluted. Accordingly, $\mathrm{Cl}$. laetevirens can be considered polluted as it contains 38.62, and $77.19 \mu \mathrm{g} \mathrm{g}^{-1} \mathrm{Cd}$ of fresh weight in reference and polluted sites, respectively. $\mathrm{Cl}$. laetevirens collected from reference and polluted sites contain high levels of $\mathrm{Pb}, \mathrm{Cu}$ and $\mathrm{Cd}$ than $P$. caerulea. This increase in metal concentration levels may be attributed to the high affinity of $\mathrm{Cl}$. laetevirens to accumulate metals, even in the relatively clean sea water. Also, the blooming and survival of $\mathrm{Cl}$. laetevirens in clean and polluted sites, referred to the tolerance characteristics enabling it to monitor a wide range of pollution levels. The present results are in agreement with that attained by Al-Homaidan et al. (2011), who referred to Cladophora as a good indicator for various heavy metal pollution conditions.

In $\mathrm{Cl}$. laetevirens, $\mathrm{Pb}$ exhibited the highest concentration levels of samples collected from the reference site, while $\mathrm{Cu}$ prevailed that collected from the polluted site. The increment in $\mathrm{Pb}$ accumulation in $\mathrm{Cl}$. laetevirens may be attributed to sewage discharge and the anthropogenic activities. This agrees, to some extent, with Pérez Lòpez et al. (2003), who reported that local industrial discharges and leaded petrol from cars and boats corresponded to $\mathrm{Pb}$ contamination. While the elevation in $\mathrm{Cu}$ levels may be depended on the nature of rocks and its erosion and the subsequent participation of their particles.

BAFs of $\mathrm{Cd}$ in $\mathrm{Cl}$. laetevirens were the highest and similar in both sites, emphasizing its potentiality for biomonitoring this metal regardless its concentration, which reflects to some extent its inability for the excretion of that metal. In general, $C l$. laetevirens can be used as an efficient biomonitor for $\mathrm{Cu}, \mathrm{Pb}$ and $\mathrm{Cd}$ pollution, while $P$. caerulea can be used as a good indicator for $\mathrm{Zn}$ pollution. This result agrees with that attained by (Al-Homaidan et al. 2011).

In spite of, the lowest performance of MPI score in this algal species due to its low sensitivity, but it provides a representative picture for the marine environment. The results evidenced that MPI was the highest in $\mathrm{Cl}$. laetevirens at reference and polluted sites, when compared to $P$. caerulea tissues. Comparing MPI for the two species, it can be concluded that $\mathrm{Cl}$. laetevirens has a great capability for metal bioaccumulation than $P$. caerulea. These results were found to be similar to that attained by Pérez - Lòpez et al. (2003). The strong correlation, based on MPI values between polluted and reference sites, proved the potential suitability of $\mathrm{Cl}$. laetevirens and $P$. caerulea to accumulate metals effectively regardless their concentrations, confirming the overall consistency in metal uptake at both sites.

The employing of Pearson's correlation and interaction between metals and their effects on Cl. laetevirens and P. caerulea draws attention to positive correlation of $\mathrm{Cd}$ with $\mathrm{Cu}$ and $\mathrm{Pb}$. Likewise, $\mathrm{Cu}$ and $\mathrm{Pb}$ are significantly correlated with each other at both sites. Noted positive significant correlations among metals may reflect a common source of occurrence and indicative of similar biogeochemical pathways for subsequent accumulation in the two sites studied. Furthermore, ANOVA analysis reveals highly significant differences between metals at both of seawater and the studied species, while non-significant for the sites detected. Generally, the highly significant difference between $\mathrm{Cl}$. laetevirens and $\mathrm{P}$. caerulea emphasized that $\mathrm{Cl}$. laetevirens may be the most suitable biomontor for heavy metal accumulation in clean and polluted sites than $P$. caerulea.

As a conclusion, algae are more appropriate bioindicators than their allied limpets. The results clearly pointed out the well documented possibility of using $\mathrm{Cl}$. 
laetevirens as a convenient monitoring tool for heavy metal contamination of coastal marine environment because of its consistency, appropriateness and reliable for monitoring.

Cl. laetevirens can be used as a good indicator of $\mathrm{Cu}, \mathrm{Pb}$ and $\mathrm{Cd}$ pollution, whereas $P$. caerulea can be utilized as an indicator of $\mathrm{Zn}$ contamination. The results predicted that $\mathrm{Cl}$. laetevirens is promising for heavy metals bioremediation than $P$. caerulea, due to its potential suitability for metals accumulation even at a very low concentration level of metals in seawater. However, $\mathrm{Cl}$. laetevirens had a higher tolerance for sewage pollution than $P$. caerulea. The present results consider a data base and useful for future studies on pollution on Libyan coastal line.

\section{REFERENCE}

Abbott, IA (1999). Marine red algae Hawahan Islands. Bishop Museum. Honolulu, Hawai.

Al-Homaidan AA, Al-Ghanayem AA, Alkhalifa AH (2011). Green Algae as Bioindicators of Heavy Metal Pollution in Wadi Hanifah Stream, Riyadh, Saudi Arabia. Inter J Water Resources and Arid Environ 1:10-15.

Association of Official Analysis Chemists (AOAC) (1980). Official Method of analysis. $13^{\text {th }}$ ed. Washington D.C.

Borradaile, LA, Potts, FA, Eastham, LES, Saunders, JT (1977). The invertebrata, 4th edition. Cambridge University Press. 820 pp.

Bradh H (2005). Heavy metals in the environment: origin, interaction and remediation. Elsevier/ Academic Press, London, pp 1067 -1075.

Chapman PM, Allen HE, Z'Graggen MN (1996). Evaluation of bioaccumulation factors in regulating metals. Environ Sci Technol 30(10): 448A-452A.

Conti ME, Cecchetti G (2003). A biomonitoring study: Trace metals in algae and mollusks from Tyrrhenian coastal areas. Environ Res 93: 99-112.

El-Adl, MF (2014): New records of marine algal species collected from Al-Jabel AlAKhdar coastline, Libya. Egypt. Acad. J. Biolog. Sci. Microbiol. 6 (2): 9-20.

Environmental Protection Agency (EPA) (2014). National Recommended Water Quality Criteria.http://water.epa.gov/scitech/swguidance/standards/criteria/current/index.cfm.

Förstner U (1985). Chemical forms and reactivities of metals in sediment. In: Leschber R, Davies RD, H'Hermite P editors. Chemical Methods of Assessing Bioavailable Metals in Sludges and Soil. Elsevier Press. London, pp. 1-30.

Harrahy EA, Clements WH (1997). Toicity and bioaccumulation of heavy metals in Chironomus tntans. Environ Toxoicol Chem 16 (2): 317 -327.

Lozano G, Hardisson A, Gutierez AJ, Lafuente MA (2003). Lead and cadmium levels in coastal benthic algae (seaweeds) of Tenerife, Canary Islands. Environ. Inter., 28: 627-631.

Marcovecchio JE (2004). The use of Micropogonias furnieri and Mugilliza as bioindicators of heavy metals pollution in La Plata river estuary, Argentina, Sci. Total Environ., 323: 219-226.

Nott JA, Nicolaidou A (1989). Metals in gastropods- metabolism and bioreduction. Mar. Environ. Res., 28 (1-4): 201 -205.

Nott JA, Nicolaidou A (1994). Variable transfer of detoxified metals from snails to hermit crabs in marine food chains. Mar. Biol., 120: 369-377.

Pérez - Lòpez M, Alonso J, Novoa-Valinas MC Melgar MJ (2003). Assessment of Heavy Metal Contamination of Seawater and Marine Limpet, Patella caerulea 
vulgata L., from Northwest Spain. J Environ Sci Health. part A Tox Hazard Subst Environ. Eng., (A38) 12: 2845-2856.

Rao SVR (1986). Urban and semiurban planning in developing countries from a water and waste water treatment point of view. Int. J. Environ. Stud., 27: 219223.

Usero J, Gonzalez-Regalado E, Gracia I (1996). Trace Metals in the Bivalve Mollusc Chamelea gallina from the Atlantic Coast of Southern Spain Mar. Pollut. Bull., 32: 305-310.

Wang WX, Caihuan K (2002). Dominance of dietary intake of cadmium and Zinc by two marine predatory gastropods. Aquat Toxicol 56 (3): 153-165.

WoRMS Editorial Board (2013). World Register of Marine Species. Available from http://www.marinespecies. org at VLIZ.

Zabochnicka-Swiatek M, Krzywonos M (2014). Potentials of biosorption and bioaccumulation processes for heavy metal removal. Pol. J. Environ. Stud., 23 (2): 551-561.

\section{ARABIC SUMMARY}

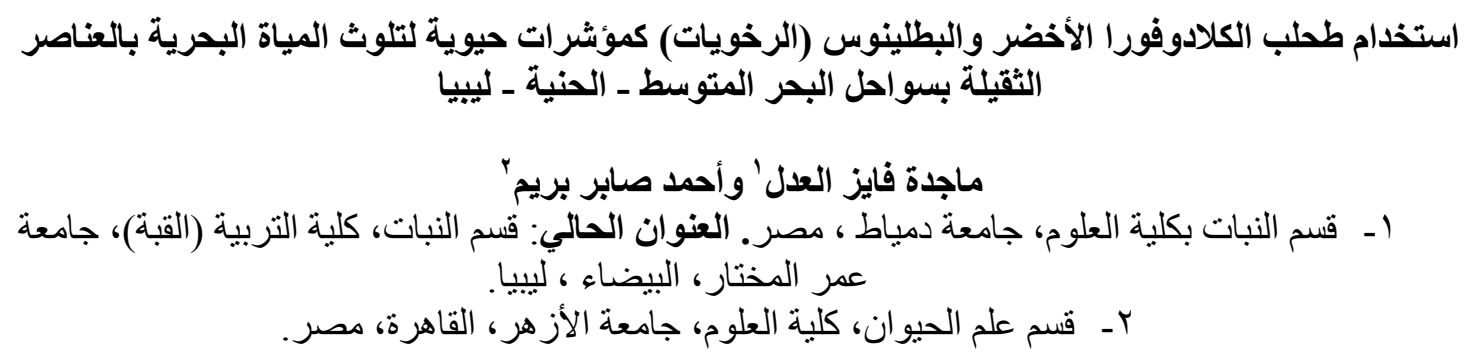

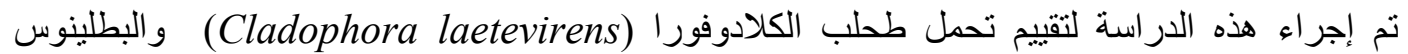
من الرخويات النامية بمياه السواحل اللييية للتلوث بالعناصر الثقيلة واستخدمهما

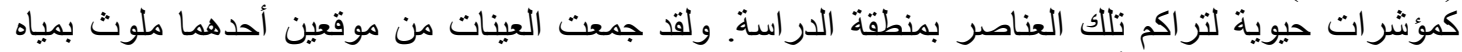

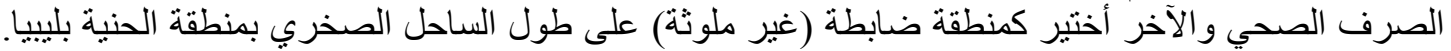

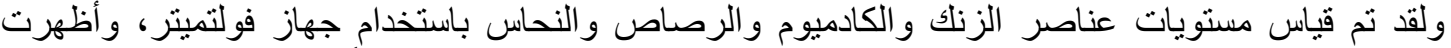

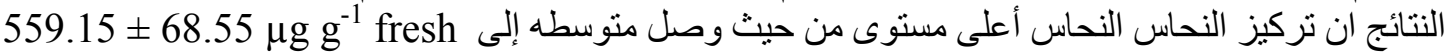
weight

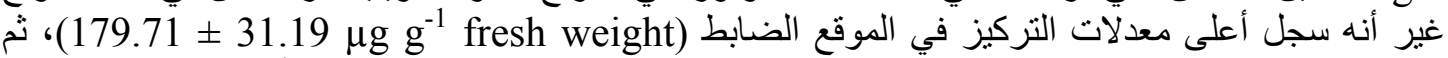

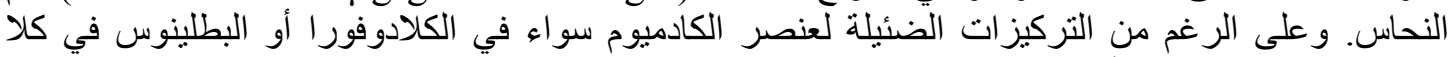

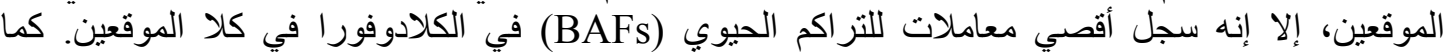

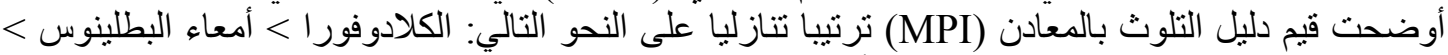

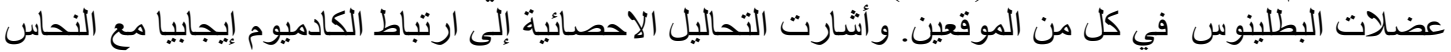

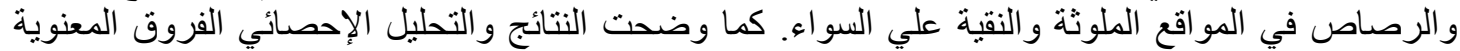

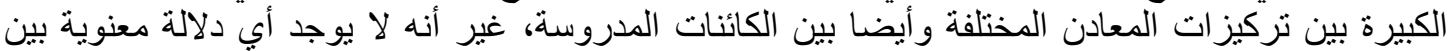

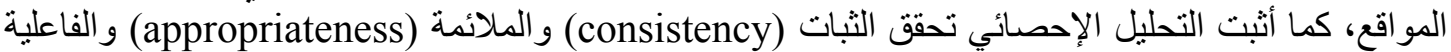

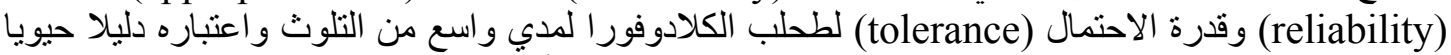

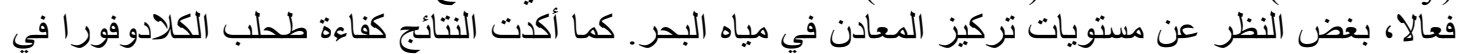
تر اكم النحاس و الرصاص ون والكادميوم وكفاءة البطلينوس في في نر اكم الزنك. لك. 